\title{
Genetic and personalized approach to valvular heart disease
}

\section{Katica Cvitkušić Lukenda ${ }^{*}$, \\ ODomagoj Vučić', Marijana Knežević Praveček', \\ CKrešimir Gabaldo', Domagoj Mišković', (D)Blaženka Miškić', (1) Ana Livun ${ }^{2}$}

'General Hospital dr. Josip Benčević, Slavonski Brod, Croatia

${ }^{2}$ University Hospital Dubrava, Zagreb, Croatia
RECEIVED:

July 9, 2021

ACCEPTED:

August 5, 2021

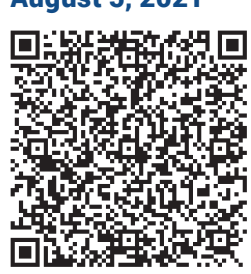

KEYWORDS: bicuspid aortic valve, calcified aortic valve disease, genetic testing, mitral valve prolapse. CITATION: Cardiol Croat. 2021;16(9-10):307. | https://doi.org/10.15836/ccar2021.307

*ADDRESS FOR CORRESPONDENCE: Katica Cvitkušić Lukenda, Opća bolnica dr. Josip Benčević, Andrije Štampara 42, HR-35000 Slavonski Brod, Croatia. / Phone: +385-98-556-576 / E-mail: kcvitkusiclukenda@gmail.com

ORCID: Katica Cvitkušić Lukenda, https://orcid.org/0000-0001-6188-0708 • Domagoj Vučić, https://orcid.org/0000-0003-3169-3658 Marijana Knežević Praveček, https://orcid.org/0000-0002-8727-7357 • Krešimir Gabaldo, https://orcid.org/0000-0002-0116-5929 Domagoj Mišković, https://orcid.org/0000-0003-4600-0498 • Blaženka Miškić, https://orcid.org/0000-0001-6568-3306 Ana Livun, https://orcid.org/0000-0002-6758-1677

\section{|||||||||||||||||||||||||||||||||||||||||||||||||||||||||||||||||||||||||||||||||||||||||||||||||||||||||||||||||||||||||||||||||||||}

Valve diseases have a large share in the total morbidity and mortality of the adult population, and can be congenital or acquired. The last few decades have seen a predominance of degenerative (calcified) heart valve diseases due to a prolonged life expectancy in economically developed countries. The therapeutic approach has remained unchanged and in the case of severe dysfunction, the valve is replaced with a mechanical or biological prosthesis, balloon valvuloplasty or valve reconstruction. The findings in understanding the development of heart valves along with human genome sequencing have led to the discovery of a genetic basis in valvular diseases ${ }^{1}$. Also, there are numerous evidence to suggest that heart valve diseases which develop in adulthood has its source in embryonic development. In this review authors will display the genetic basis of the two most common inherited valvular diseases: bicuspid aortic valve and mitral valve prolapse, as well as a review of the findings suggesting a genetic contribution to calcified aortic valve disease ${ }^{2}$. In addition, this review will include a review of the guidelines and benefits of genetic testing, as well as highlight the need to include genetic counseling in families with proven or suspected malformations. Linking genetic information to the clinical phenotype (Table 1) and potential outcomes of surgical treatment leads to a personalized approach to each patient ${ }^{3}$

TABLE 1. Gene mutations associated with valvular heart disease.

\begin{tabular}{lllll}
\hline & Location & Gene & Inheritance & Phenotype \\
\hline Bicuspid aortic valve & & & & \\
\hline Syndromic & $17 \mathrm{q} 24.3$ & KCNJ2 & $\mathrm{AD}$ & Andersen syndrome \\
\hline Nonsyndromic & $9 \mathrm{q} 34.3$ & NOTCH1 & $\mathrm{AD}$ & AOVD1 \\
& $20 \mathrm{q} 13.33$ & GATA5 & $\mathrm{AD}, \mathrm{AR}$ & CHTD5 \\
& $15 \mathrm{q} 22.31$ & SMAD6 & $\mathrm{AD}$ & AOVD2 \\
& $11 \mathrm{q} 24.2$ & ROB04 & $\mathrm{AD}$ & AOVD3 \\
\hline Mitral valve prolapse & & & & \\
\hline Syndromic & $15 \mathrm{q} 21.1$ & FBN1 & $\mathrm{AD}$ & Marfan syndrome \\
& $9 \mathrm{q} 22.33$ & TGFBR1 & $\mathrm{AD}$ & Loeys-Dietz syndrome 1 \\
& $3 \mathrm{p} 24.1$ & TGFBR2 & $\mathrm{AD}$ & Loeys-Dietz syndrome2 \\
& $7 \mathrm{q} 21.3,12 \mathrm{q} 13.1$, & Collagen types & $\mathrm{AR}, \mathrm{AD}$ & Ol 1,Ehlers-Danlos syndrome, cardiac \\
& $2 \mathrm{q} 32.2,9 \mathrm{q} 34.3$ & I-III, V/ XI & $\mathrm{AD}, \mathrm{AD}$ & valvular type \\
\hline Nonsyndromic & $\mathrm{Xq28}$ & Filamin A & $\mathrm{XL}$ & Cardiac valvular dysplasia \\
\hline Aortic valve stenosis & & & & \\
\hline CAVD & $9 \mathrm{q} 34.3$ & NOTCH1 & $\mathrm{AD}$ & AOVD1 \\
\hline
\end{tabular}

$A D$ - autosomal dominant, $A R$ - autosomal recessive, AOVD - aortic valve disease, CHTD - congenital heart disease, $\mathrm{OI}$ - osteogenesis imperfecta, $\mathrm{XL}$ - X-linked, CAVD - calcified aortic valve disease.

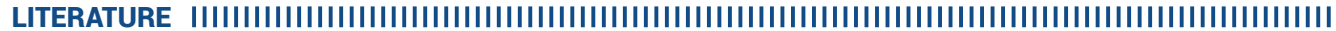

1. Blue GM, Kirk EP, Giannoulatou E, Sholler GF, Dunwoodie SL, Harvey RP, et al. Advances in the Genetics of Congenital Heart Disease: A Clinician's Guide. J Am Coll Cardiol. 2017 Feb 21;69(7):859-870. https://doi.org/10.1016/j.jacc.2016.11.060

2. Koenig SN, Lincoln J, Garg V. Genetic basis of aortic valvular disease. Curr Opin Cardiol. 2017 May:32(3):239-245. https://doi.org/10.1097/ HCO.0000000000000384

3. Diz OM, Toro R, Cesar S, Gomez 0, Sarquella-Brugada G, Campuzano 0. Personalized Genetic Diagnosis of Congenital Heart Defects in Newborns. J Pers Med. 2021 Jun 16;11(6):562. https://doi.org/10.3390/jpm11060562
5. kongres Radne skupine za bolesti srčanih zalistaka Hrvatskoga kardiološkog društva s međunarodnim sudjelovanjem $5^{\text {th }}$ Congress of the Working Group on Valvular Diseases of the Croatian Cardiac Society with international participation September 2-4, 2021, Zagreb, Croatia
Cardiologia Croatica $\square$ 2021;16(9-10):307. 